\title{
Urban Cleanliness a Bottom-up Approach: Perspectives from Shopkeepers
}

\author{
Gauri Modwel ${ }^{1}$, Sudhir Kumar Jain ${ }^{2}$ \\ ${ }^{1}$ Department of Economics, New Delhi Institute of Management, Delhi, India \\ ${ }^{2}$ Department of Economics, Netaji Subhas Institute of Technology, Delhi, India \\ Email address: \\ gauri.modwel@ndimdelhi.org (G. Modwel), skjain51@hotmail.com (S. K. Jain) \\ ${ }^{*}$ Corresponding author
}

\section{To cite this article:}

Gauri Modwel, Sudhir Kumar Jain. Urban Cleanliness a Bottom-up Approach: Perspectives from Shopkeepers. American Journal of Environmental and Resource Economics. Vol. 6, No. 2, 2021, pp. 66-76. doi: 10.11648/j.ajere.20210602.15

Received: May 22, 2021; Accepted: June 15, 2021; Published: June 22, 2021

\begin{abstract}
The most important visible difference between a developed country and a developing country is the level of cleanliness as witnessed by the people. Most of the NRIs give preference to cleanliness and continue to live abroad. If India could be a clean country, it would be an equally preferred place to live for majority of the NRIs as well as those who live here but aspire to go abroad or live there. Filthiness adversely affects the health and leads to unavoidable diseases. Further, in clean India, the tourist traffic from developed as well as all other countries will also increase, which will substantially enhance foreign exchange earnings for the nation and, simultaneously, generate significant employment. In this context, this paper is attempted to emphasize problem of lack of cleanliness encompassing waste management and littering in Delhi which is capital of India. The main aim of this paper is to seek opinions from one of the important stakeholders, i.e. shopkeepers, based on important parameters of cleanliness as ways to ensure total cleanliness, limitations or constraints towards lack of cleanliness and extent of contribution towards creation of garbage in the various major markets of Delhi, capital of India. This is empirical research paper based on exploratory research. In this paper, purposive sampling method is used to select sample of shopkeepers of the market of 4 regions in Delhi. Three categories of shopkeepers were surveyed through structured questionnaire. First category of shopkeepers surveyed had up to 5 employees. Second category was the ones which had 6-20 employees and the third category of shopkeepers has more than 20 employees. To test the hypothesis that shopkeepers with up to 5 employees, 6-20 employees and more than 20 employees have statistically significant different opinions regarding cleanliness, an independent t- test is performed. After testing hypothesis, it is concluded that the opinion of all three categories of shopkeepers from different markets in Delhi on all parameters, ways to ensure total cleanliness, limitations or constraints towards lack of cleanliness and extent of contribution towards creation of garbage, are not statistically significantly different therefor all the 3 categories of shopkeepers are having consensus. Hence, based on these findings, there is future scope of preparing paper on policy recommendations for cleanliness in Delhi to the state government.
\end{abstract}

Keywords: Waste Management, Littering, Shopkeepers, Urban Cleanliness

\section{Introduction}

Cleanliness is an integral part of life. It has been mostly associated with the concept of personal hygiene but the concept extends beyond the sphere of personal and into the sphere of social and the political. Cleanliness is not just about maintaining the state of being free and clean from germs, trash or waste in personal lives and homes, but also doing the same in the larger social spaces. The concept of urban cleanliness stems out of the need to free the cities from the clutches of waste, dirt and litter. Urban cleanliness requires micro managing process, starting at homes with an objective to eliminate dirt, waste, and garbage from the cities at large.

The urbanization processes have sparked a rapid physical growth of urban centres. Urban areas are getting crowded with high population concentrations. At the moment, cities are compact with physical growth to optimize urban space for diverse economic activities. Lack of cleanliness in a city is often blamed on the local authority as one of the key duties 
of a local authority is to ensure urban cleanliness. The problem of urban cleanliness is a common glimmer in India. While littering is considered an unacceptable behaviour, it is still condoned socially and in India it is not condemned. This is possibly because the non-littering community hadn't been completely established. Littering is accepted, without strict social approval for litterers. Since littering in urban areas is rampant, maintaining urban cleanliness is a challenge for local authorities.

Some studies have indicated litter presence may promote littering. [1, 6]. In addition, people prefer to indulge in littering (dumping) without much thought [2]. There are various methods of encouraging urban cleanliness, ranging from previous approaches to a result approach [6]. Previous approaches consist of prompts / verbal or written notes, awareness / education, modelling or presentations, goalsettings or communication techniques, development or design procedures $[5,6]$. Strategies for effect include incentives and penalties [6]. Both ontological and result approaches have typically been found to be effective in reducing litter. Concerted and coordinated efforts are more likely to succeed in reducing littering [7]. To effectively curb littering, it is necessary to have awareness, regulation, engineering (infrastructure) and public participation.

Absence of one dimension will cause the others less efficient. For example, an educational program alone does not result in positive improvements in the long term. In addition, nonlittering messages must be aimed at individuals likely to produce litter. While there is little done to study the urban cleanliness efforts, this study is a modest attempt towards understanding the concept of urban cleanliness with respect to Delhi and to develop a comprehensive plan for making Delhi clean at par with cities in developed nations.

India has a burgeoning waste problem. We're witnessing rapid urbanization even as resources grow scarce. Among the myriad set of issues plaguing any Indian city or town is Municipal Solid Waste (MSW) collection and Management. There are a myriad set of agencies that have come up with estimations of India's waste generation. As per estimation, 172 countries in total generate 1.47 billion tons of Municipal solid waste every year. [8]. India alone produces 1.5 lakh tons of municipal waste in a day, according to the Central Pollution Control Board (CPCB), out of which only 30\% is treated. It projects the volume of municipal waste to increase to 125 million tons by 2031. According to the Energy and Resources Institute, the annual Municipal waste generation in India is 62 million. Construction and demolition waste accounts for 500-700 million tons per annum, Hazardous waste accounts for 7.9 million tons per annum, Nonhazardous 200 million tons per annum, Biomedical accounts for 1.5 lakh tons annually and e-waste amounts to 8 lakh tons.

In Delhi alone, it was estimated that the daily solid waste generation rate would increase at 95\% between 2011 and 2024. [23]. The average collection efficiency of MSW is reported as $80.28 \%$ in 2014 ranging from $22 \%$ to $90 \%$. The waste characterization showed that MSW typically contains $51 \%$ organics, $17 \%$ recyclables, $11 \%$ hazardous waste, and
$21 \%$ inert materials (Ministry of Environment and Forest, 2010). Urbanisation, population explosion and changing consumption patterns in global villages are all cited as reasons for this growth. But a corollary study indicates that municipal waste generation in major Indian cities is in fact outgrowing population growth [13]. It is estimated that India would need a landfill site the size of Bengaluru to store all its waste by 2030 . Since consumption has yet to see a decline among the urban dwellers, it becomes imperative to devise a sound waste management policy to dispose of or re-energize waste efficiently with minimum harm to an already deteriorating ecosystem.

A sound waste management strategy would be one that completes the cycle of successful collection of waste, transportation, treatment and disposal. The sheer volume of waste produced has only increased but not without waste management strategies. Their application, at least in the Indian context, leaves a lot to be desired primarily because one or all of the elements of waste management, are inefficacious. Waste management is after all, a multidimensional project with numerous dynamic parts involved at any stage. There are socio-economic-environmental forces at play that should be incorporated to extract maximum benefits. Indian cities need to come up with specific application of waste strategies that involve various stakeholders pursuing a singular vision with clarity of their role in the larger framework.

The main problem in urban India is that roads and streets are very dirty and filthy largely because vendors, shopkeepers and consumers are lacking civic sense and traditionally they are habitual of littering. Filthiness adversely affects the health and leads to otherwise unavoidable diseases. Fitly Roads and streets also hampers footfall of from developed as well as all other countries. Whereby, fall in tourist traffic can lead another problem of unemployment because of decline in foreign exchange earnings.

As per above mentioned problem, The main objective of this paper is to seek opinions from one of the important stakeholders, i.e. shopkeepers based on parameters of cleanliness as ways to ensure total cleanliness, limitations or constraints towards lack of cleanliness and extent of contribution towards creation of garbage in the various major markets of Delhi, capital of India.

\section{Literature Review}

Before beginning the analysis, it is important to view the evolution of waste management in the Indian context. The focus on solid waste management as we understand it today has only very recently gathered traction in India. Till the 1980s, Industrial waste, municipal sewage and industrial waste constituted the definition of waste.

It was in the 1980s, following the Bhopal gas tragedy, that the Ministry of Forest and Environment enacted the Environment (Protection) Act 1986 took the first steps towards waste management and created the hazardous waste 
management rules and subsequently bio medical waste. But they were remarkable for ignoring MSW, segregation or guidelines for waste collectors. The focus remained on safety from environmental hazards. In the 2000s, with increasing awareness on sustainability and climate change, MSW became the linchpin to Solid Waste Management in India. A series of policies were enacted like the Municipal Solid Wastes (Management and Handling) Rules (2000), the National Environmental Policy (2006), the National Urban Sanitation policy (2008) and the National Action Plan for Climate Change (2009). Each progressively building on to the policies that came before it. The Swachh Bharat Abhiyan (2014), arguably, provided the biggest push in the direction of sanitation in India that reinvigorated Waste Management as an important facet of environmental conservation [20].

In 2016, the Union Ministry of Environment, Forests and Climate Change (MoEF\&CC) notified a series of waste management rules such as E-Waste Management Rules 2016, Plastic Waste Management Rules 2016, Construction and Demolition Waste Management Rules 2016, Hazardous Waste Management Rules 2016, Bio-medical Waste Management Rules 2016 and the Solid Waste Management Rules. The Solid Waste Management Rules were a revision of the preceding Municipal Solid Wastes Rules (2000).

The word "Municipal" was removed in the new rules to increase the scope of waste management beyond the Municipal area to urban conglomerations, census towns, special economic zones etc. The new rules for the first time highlighted the responsibility of the waste generators and called for segregation at source to channelize waste to wealth by recovery, reuse and recycling with the hopes to reduce burden on landfills (Press Information Bureau, GOI). Waste generators here would include households, event organizers, street vendors, RWA and market Associations, Gated communities with more than 5000 sq. meters in area and hotels and restaurants.

Extended Producer Responsibility is also a feature of the new rules that separates them from 2000's regulations. They charge producers of diapers, sanitary napkins to provide pouches for suitable disposal and manufacturers of disposable material like glass, tin, plastic packets etc. to provide financial assistance to local authorities working on waste management. They designated the Ministry of Urban with more responsibilities to formulate a National Policy and Strategy on Solid Waste Management in consultation with stakeholders that shall be the guideline for the states and urban local bodies to follow.

The SWM2016 rules mandated the state governments to incorporate informal waste workers and the urban local bodies to specify bye laws to execute and monitor the establishment of solid waste treatment facilities, waste to energy facilities, waste to compost facilities, sanitary landfills, and decide on user fines for households and spot fines for littering. Overseeing the execution and monitoring of these rules is the Central Monitoring Committee under the Secretary of the MoEF\&CC. The SWM2016 rules specified a time frame for its implementation and the frequency with which the implementation at various stages would be reviewed. The success of this ISWM hierarchy is incumbent on an efficient implementation of these rules.

In a study of Bhopal city to judge their MSWM found the city to be mired in the same issues as most Indian cities. There are unscientific landfills, lack of equipment and funds, inadequate manpower, improper management struggling to handle 800 tons of MSW generated in a day out of which only $15 \%$ is of high calorific content. They suggest installing twice the number of collection bins currently available and segregation at source into at least wet and dry waste. To tackle uncollected waste coagulated on the city streets, they recommend increasing the number of staffs. This could improve waste collection in the cities. Since landfill is the most popular outlet for MSWM, it is essential to improve the transportation to these facilities [19].

A study has identified multiple gaps in the MSWM done in the city of Patna. The study found minimal implementation of SWM rules 2016 and little public participation. There is a confusion on the role of the economic benefits of sustainable recycling were not realised by the authorities or the public. Sustainable recycling also factors in the predicament of the informal sector that has little attention given to its working conditions. The local government provides no subsidy for recycling paper and plastic machines thereby shutting down any recycling unit that had been in operation before. This highlights the issue of integrating all stakeholders in society. Without government support and incentives, there will be little improvement [22].

A study in Sweden could make a case for the benefits of integrated waste management and how to go about it Two municipally owned companies combine waste collection, waste transformation and marketing for the recycled products to reenter the economy. These companies operate in a highly regularized environment with permits that are not easily earned and strong political supervision. The companies charge the municipalities a fee that is decided by the municipalities in consultation with the companies, to collect waste from industries, households and institutions. There is emphasis on minimizing waste sent to landfills so the companies have developed waste processing techniques for waste generation like biogas fermentation and thermal processing respectively. The companies play their part in publicity and generating awareness about the benefits of MSWM [3].

The importance of community awareness and campaigns is reinstated in a study conducted in Surabaya, Indonesia where inhabitants of a slum colony participated in the public commitment and psychoeducation program to learn and practice clean and healthy living behaviors. Their research design consisted of a pre-test and pro-test procedure to ascertain the efficacy of the experiment. A public commitment set the stakes for individuals to keep up with their end of the bargain and the results showed the participants rising to the occasion [10].

Examples of successful waste management can also be found in India. Ward 40 Katraj in Pune city practices zero 
waste and depends on zero landfills. It achieved the status in 2012 and had retained its status for 7 years. The idea of a circular model where one either retrieves vital resources from the waste disposed of or recycles all the waste that is possible. There are a lot of benefits to be earned from becoming a zero-waste economy. It is better for the environment and sustains the economy for the myriad ways in which it provides employment in collection, handling, and recycling, composting, deriving refuse derived fuel (RDF) etc. [15].

\section{Research Methodology}

Qualitative and quantitative empirical research is conducted through survey and interviews of the Shopkeepers to assess their attitude towards cleanliness to sustain clean environment in Delhi. Primary data is collected through a structured questionnaire based on 5 point likert scale. A sample of 106 shopkeepers of major markets of all four regions of Delhi is covered in the Survey. Purposive sampling is used to select sample of shopkeepers from all four regions of Delhi for equal representation.

In an attempt to understand the difference of opinions of shopkeepers with different number of employees about contribution towards creation of Garbage, limitations or constraints for lack of cleanliness and various effective ways to ensure total cleanliness. It is Hypothesized that opinions of shopkeepers with up to 5 employees, 6-20 employees and more than 20 employees regarding the parameters, extent of the contribution towards creation of garbage, limitations or constraints for lack of cleanliness and various effective ways to ensure total cleanliness are associated with statistically significant different mean. To test the hypothesis an independent t-test is performed.

\section{Results and Discussion}

\subsection{Contributors Towards Creation of Garbage}

In an attempt to assess the opinion of shopkeepers based on three categories as per number of employees (shopkeepers with 5 employees and 6-20 employees and more than 20 employees) about main contributors or causes towards creation of garbage (as per Table 1) it is found that pedestrians (adults), shopkeepers with up to 5 employees $(N=82)$ was associated with a $M=3.21 \quad(S D=1.01)$. By comparison shopkeepers with $6-20$ employees $(N=19)$ were associated with $M=2.53(S D=0.77)$ and shopkeepers with more than 20 employees $(N=5)$ were associated $M=1.2$ $(S D=1)$. The independent t-statistics associated with shopkeepers with up to 5 employees was $t(99)=-1.28$, $\mathrm{p}=0.202$. Whereas $\mathrm{t}$ statistics for shopkeepers with 6 to 20 employees was $\mathrm{t}(34)=-1.52, \mathrm{p}=0.137$ and $\mathrm{t}$ statistics associated with shopkeepers with more than 20 employees $t$ $(4)=0.45, \quad p=0.674$. Street vendors/ Eatable sellers, shopkeepers with up to 5 employees $(N=82)$ was associated with a $M=2.78(S D=1.34)$. By comparison shopkeepers with 6 - 20 employees $(N=19)$ were associated with $M=2.95$
$(S D=2.01)$ and shopkeepers with more than 20 employees $(N=5)$ were associated $M=2.8(S D=1.09)$. The independent tstatistics associated with shopkeepers with up to 5 employees was $\mathrm{t}(99)=-0.44, \mathrm{p}=0.714$. Whereas $\mathrm{t}$ statistics for shopkeepers with 6 to 20 employees was $t(21)=-0.34, p=0.7$ and $t$ statistics associated with shopkeepers with more than 20 employees $\mathrm{t}(4)=-0.03, \mathrm{p}=0.971$. Buyers from vendors and hawkers, shopkeepers with up to 5 employees $(N=82)$ was associated with a $M=3.28 \quad(S D=0.94)$. By comparison shopkeepers with $6-20$ employees $(N=19)$ were associated with $M=3.74(S D=0.80)$ and shopkeepers with more than 20 employees $(N=5)$ were associated $M=3.2(S D=1.09)$. The independent t-statistics associated with shopkeepers with up to 5 employees was $\mathrm{t}(99)=-1.94, \mathrm{p}=0.66$. Whereas $t$ statistics for shopkeepers with 6 to 20 employees was $t(30)=-2.14$, $\mathrm{p}=0.040$ and $\mathrm{t}$ statistics associated with shopkeepers with more than 20 employees $\mathrm{t}(4)=0.16, \mathrm{p}=0.88$. Gutka consumers, shopkeepers with up to 5 employees $(N=82)$ was associated with a $M=3.70 \quad(S D=0.97)$. By comparison shopkeepers with $6-20$ employees $(N=19)$ were associated with $M=3.79(S D=1.13)$ and shopkeepers with more than 20 employees $(N=5)$ were associated $M=4 \quad(S D=1.22)$. The independent t-statistics associated with shopkeepers with up to 5 employees was $t(99)=-0.36, p=0.66$. Whereas $t$ statistics for shopkeepers with 6 to 20 employees was $t(24)=-0.33$, $\mathrm{p}=0.741$ and $\mathrm{t}$ statistics associated with shopkeepers with more than 20 employees $t(4)=-0.54, p=0.612$. Cycle Rikshaw/ Auto-Taxi Drivers, shopkeepers with up to 5 employees $(N=82)$ was associated with a $M=2.54(S D=1.48)$. By comparison shopkeepers with $6-20$ employees $(N=19)$ were associated with $M=2(S D=0.70)$ and shopkeepers with more than 20 employees $(N=5)$ were associated $M=2$ $(S D=1.22)$. The independent t-statistics associated with shopkeepers with up to 5 employees was $t(99)=1.50$, $\mathrm{p}=0.136$. Whereas $\mathrm{t}$ statistics for shopkeepers with 6 to 20 employees was $\mathrm{t}(41)=1.97, \mathrm{p}=0.055$ and $\mathrm{t}$ statistics associated with shopkeepers with more than 20 employees $\mathrm{t}(6)=1.50$, $\mathrm{p}=0.179$. Cycle Rikshaw/ Auto-Taxi/ Car passengers, shopkeepers with up to 5 employees $(N=82)$ was associated with a $M=2.72(S D=1.45)$. By comparison shopkeepers with 6 - 20 employees $(N=19)$ were associated with $M=2.26$ $(S D=0.99)$ and shopkeepers with more than 20 employees $(N=5)$ were associated $M=2(S D=0.70)$. The independent tstatistics associated with shopkeepers with up to 5 employees was $\mathrm{t}(85)=1.09, \mathrm{p}=0.276$. Whereas $\mathrm{t}$ statistics for shopkeepers with 6 to 20 employees was $\mathrm{t}(38)=1.60$, $\mathrm{p}=0.109$ and $\mathrm{t}$ statistics associated with shopkeepers with more than 20 employees $t(6)=2.00, p=0.086$.

Road Digging (Repair workers of MTNL/BSES etc.), shopkeepers with up to 5 employees $(N=82)$ was associated with a $M=2.93(S D=1.41)$. By comparison shopkeepers with 6 - 20 employees $(N=19)$ were associated with $M=2.84$ $(S D=1.92)$ and shopkeepers with more than 20 employees $(N=5)$ were associated $M=2.4(S D=1.51)$. The independent tstatistics associated with shopkeepers with up to 5 employees was $\mathrm{t}(99)=0.21, \mathrm{p}=0.827$. Whereas $\mathrm{t}$ statistics for shopkeepers with 6 to 20 employees was $t(22)=0.18$, 
$\mathrm{p}=0.858$ and $\mathrm{t}$ statistics associated with shopkeepers with more than 20 employees $t(4)=0.75, p=0.487$. Non- removal of Malba after renovation work, shopkeepers with up to 5 employees $(N=82)$ was associated with a $M=2.48(S D=1.28)$. By comparison shopkeepers with $6-20$ employees $(N=19)$ were associated with $M=1.95(S D=1.07)$ and shopkeepers with more than 20 employees $(N=5)$ were associated $M=2.2$ $(S D=1.30)$. The independent t-statistics associated with shopkeepers with up to 5 employees was $t(99)=1.65$, $\mathrm{p}=0.101$. Whereas $\mathrm{t}$ statistics for shopkeepers with 6 to 20 employees was $\mathrm{t}(31)=1.85, \mathrm{p}=0.074$ and $\mathrm{t}$ statistics associated with shopkeepers with more than 20 employees $t$
(4) $=0.45, p=0.667$. Dry leaves burning (banned by SC), shopkeepers with up to 5 employees $(N=82)$ was associated with a $M=2.34(S D=2.72)$. By comparison shopkeepers with 6 - 20 employees $(N=19)$ were associated with $M=1.95$ $(S D=2.91)$ and shopkeepers with more than 20 employees $(N=5)$ were associated $M=2.2(S D=0.44)$. The independent tstatistics associated with shopkeepers with up to 5 employees was $\mathrm{t}(99)=-0.26, \mathrm{p}=0.793$. Whereas $\mathrm{t}$ statistics for shopkeepers with 6 to 20 employees was $t(25)=-0.25$, $\mathrm{p}=0.803$ and $\mathrm{t}$ statistics associated with shopkeepers with more than 20 employees $\mathrm{t}(34)=3.15, \mathrm{p}=0.003$.

Table 1. Extent of Contribution towards Creation of Garbage by Different Types of Persons or Causes.

\begin{tabular}{|c|c|c|c|c|c|c|c|c|}
\hline \multirow{2}{*}{ Parameters } & \multirow{2}{*}{ No of Employees in shops } & \multirow{2}{*}{$\mathbf{N}$} & \multirow{2}{*}{ Mean } & \multirow{2}{*}{ Std. Deviation } & \multicolumn{4}{|c|}{ t-test for Equality of Means } \\
\hline & & & & & $\mathbf{t}$ & dof & Sig. (2-tailed) & Mean Difference \\
\hline \multirow{3}{*}{ Pedestrians (Adults) } & up to 5 & 82 & 3.21 & 1.01 & -1.28 & 99 & 0.202 & -0.319 \\
\hline & 6 to 20 & 19 & 3.53 & 0.77 & -1.52 & 34 & 0.137 & -0.319 \\
\hline & More than 20 & 5 & 3 & 1 & 0.45 & 4 & 0.674 & 0.207 \\
\hline \multirow{3}{*}{$\begin{array}{l}\text { Street Vendors/ } \\
\text { Eatable Sellers }\end{array}$} & up to 5 & 82 & 2.78 & 1.34 & -0.44 & 99 & 0.66 & -0.167 \\
\hline & 6 to 20 & 19 & 2.95 & 2.01 & -0.34 & 21 & 0.734 & -0.167 \\
\hline & More than 20 & 5 & 2.8 & 1.09 & -0.03 & 4 & 0.971 & -0.02 \\
\hline \multirow{2}{*}{$\begin{array}{l}\text { Buyers from Vendors } \\
\text { Hawkers }\end{array}$} & 6 to 20 & 19 & 3.74 & 0.80 & -2.14 & 30 & 0.040 & -0.456 \\
\hline & More than 20 & 5 & 3.2 & 1.09 & 0.16 & 4 & 0.88 & 0.08 \\
\hline \multirow{3}{*}{$\begin{array}{l}\text { Gutka Consumers } \\
\text { (Spitting, Littering) }\end{array}$} & up to 5 & 82 & 3.7 & 0.97 & -0.36 & 99 & 0.714 & -0.094 \\
\hline & 6 to 20 & 19 & 3.79 & 1.13 & -0.33 & 24 & 0.741 & -0.094 \\
\hline & More than 20 & 5 & 4 & 1.22 & -0.54 & 4 & 0.612 & -0.305 \\
\hline \multirow{2}{*}{$\begin{array}{l}\text { Cycle Rikshaw/ Auto- } \\
\text { Taxi Drivers }\end{array}$} & up to 5 & 82 & 2.54 & 1.48 & 1.50 & 99 & 0.136 & 0.537 \\
\hline & 6 to 20 & 19 & 2 & 0.94 & 1.97 & 41 & 0.055 & 0.537 \\
\hline \multirow{2}{*}{$\begin{array}{l}\text { Cycle Rikshaw/ Auto- } \\
\text { Taxi/ Car passengers }\end{array}$} & 6 to 20 & 19 & 2.26 & 0.99 & 1.60 & 38 & 0.109 & 0.456 \\
\hline & More than 20 & 5 & 2 & 0.70 & 2.00 & 6 & 0.086 & 0.72 \\
\hline \multirow{6}{*}{$\begin{array}{l}\text { Road Digging (Repair } \\
\text { workers of } \\
\text { MTNL/BSES etc.) } \\
\text { Non- removal of } \\
\text { Malba after renovation } \\
\text { work }\end{array}$} & up to 5 & 82 & 2.93 & 1.41 & 0.21 & 99 & 0.827 & 0.085 \\
\hline & 6 to 20 & 19 & 2.84 & 1.92 & 0.18 & 22 & 0.858 & 0.085 \\
\hline & More than 20 & 5 & 2.4 & 1.51 & 0.75 & 4 & 0.487 & 0.527 \\
\hline & up to 5 & 82 & 2.48 & 1.28 & 1.65 & 99 & 0.101 & 0.528 \\
\hline & 6 to 20 & 19 & 1.95 & 1.07 & 1.85 & 31 & 0.074 & 0.528 \\
\hline & More than 20 & 5 & 2.2 & 1.30 & 0.45 & 4 & 0.667 & 0.276 \\
\hline \multirow{3}{*}{$\begin{array}{l}\text { Dry leaves burning } \\
\text { (banned by SC) }\end{array}$} & up to 5 & 82 & 2.34 & 2.72 & -0.26 & 99 & 0.793 & -0.185 \\
\hline & 6 to 20 & 19 & 2.53 & 2.91 & -0.25 & 25 & 0.803 & -0.185 \\
\hline & More than 20 & 5 & 1.2 & 0.44 & 3.15 & 34 & 0.003 & 1.141 \\
\hline Animals eating from & up to 5 & 82 & 1.85 & 1.41 & -1.04 & 99 & 0.3 & -0.409 \\
\hline leftovers (eatables left & 6 to 20 & 19 & 2.26 & 2.02 & -0.83 & 22 & 0.412 & -0.409 \\
\hline by people) & More than 20 & 5 & 1 & 0 & 5.46 & 81 & 0 & 0.854 \\
\hline $\begin{array}{l}\text { Animal Shit (Cow- } \\
\text { dung/Dog-potty) }\end{array}$ & up to 5 & 82 & 2.18 & 1.57 & -0.31 & 99 & 0.757 & -0.133 \\
\hline
\end{tabular}

Animals eating from leftovers (eatables left by people), shopkeepers with up to 5 employees $(N=82)$ was associated with a $M=1.85(S D=1.41)$. By comparison shopkeepers with 6 - 20 employees $(N=19)$ were associated with $M=2.26$ $(S D=2.02)$ and shopkeepers with more than 20 employees $(N=5)$ were associated $M=1 \quad(S D=0.0)$. The independent tstatistics associated with shopkeepers with up to 5 employees was $\mathrm{t}(99)=-1.04, \mathrm{p}=0.30$. Whereas $\mathrm{t}$ statistics for shopkeepers with 6 to 20 employees was t $(22)=-0.83$, $\mathrm{p}=0.412$ and $\mathrm{t}$ statistics associated with shopkeepers with more than 20 employees $\mathrm{t}(81)=5.46, \mathrm{p}=0.00$. Animal Shit (Cow-dung/Dog-potty), shopkeepers with up to 5 employees $(N=82)$ was associated with a $M=2.18(S D=1.57)$. By comparison shopkeepers with $6-20$ employees $(N=19)$ were associated with $M=2.32(S D=2.11)$ and shopkeepers with more than 20 employees $(N=5)$ were associated $M=1.2$ $(S D=0.44)$. The independent t-statistics associated with shopkeepers with up to 5 employees was $t(99)=-0.31$, $p=0.757$ Whereas $t$ statistics for shopkeepers with 6 to 20 employees was $\mathrm{t}(22)=-0.25, \mathrm{p}=0.798$ and $\mathrm{t}$ statistics associated with shopkeepers with more than 20 employees $t$ $(11)=3.71, \mathrm{p}=0.003$.

\subsection{Constraints For Lack of Cleanliness}

While testing the hypothesis that the opinions of 
shopkeepers with 5 employees, six to twenty and more than twenty employees were associated with statistically significant different mean, an independent t-test was performed. As it can be seen in Table 2, for the parameter littering by people coming to markets, shopkeepers with up to 5 employees $(N=82)$ was associated with a $M=3.48$ $(S D=0.94)$. By comparison shopkeepers with $6-20$ employees $(N=19)$ were associated with $M=3.68(S D=0.82)$ and shopkeepers with more than 20 employees $(N=5)$ were associated $M=3.4(S D=0.89)$. The independent t-statistics associated with shopkeepers with up to 5 employees was $t$ $(99)=-0.88, p=0.377$ Whereas t statistics for shopkeepers with 6 to 20 employees was $\mathrm{t}(30)=-0.96, \mathrm{p}=0.340$ and $\mathrm{t}$ statistics associated with shopkeepers with more than 20 employees $t$ (4) $=0.18, p=0.863$. Littering by different transport drivers shopkeepers with up to 5 employees $(N=82)$ was associated with a $M=2.35(S D=0.99)$. By comparison shopkeepers with $6-20$ employees $(N=19)$ were associated with $M=2.26$
$(S D=0.99)$ and shopkeepers with more than 20 employees $(N=5)$ were associated $M=2.40(S D=0.89)$. The independent t-statistics associated with shopkeepers with up to 5 employees was $\mathrm{t}(99)=0.35, \mathrm{p}=0.722$ Whereas $\mathrm{t}$ statistics for shopkeepers with 6 to 20 employees was $t(27)=0.35$, $\mathrm{p}=0.723$ and $\mathrm{t}$ statistics associated with shopkeepers with more than 20 employees $t(14)=-0.11, p=0.916$. NonAvailability of suitable size dustbins, shopkeepers with up to 5 employees $(N=82)$ was associated with a $M=3.99$ $(S D=1.24)$. By comparison shopkeepers with $6-20$ employees $(N=19)$ were associated with $M=3.74(S D=1.24)$ and shopkeepers with more than 20 employees $(N=5)$ were associated $M=4.20(S D=0.83)$. The independent t-statistics associated with shopkeepers with up to 5 employees was $t$ $(99)=0.79, p=0.426$ whereas $t$ statistics for shopkeepers with 6 to 20 employees was $\mathrm{t}(26)=0.79, \mathrm{p}=0.433$ and $\mathrm{t}$ statistics associated with shopkeepers with more than 20 employees $t$ $(5)=-0.53, \mathrm{p}=0.616$.

Table 2. Extent of various limitations/ Constraints for lack of cleanliness.

\begin{tabular}{|c|c|c|c|c|c|c|c|c|}
\hline \multirow{2}{*}{ Parameters } & \multirow{2}{*}{ No of Employees in shops } & \multirow{2}{*}{$\mathbf{N}$} & \multirow{2}{*}{ Mean } & \multirow{2}{*}{ Std. Deviation } & \multicolumn{4}{|c|}{ t-test for Equality of Means } \\
\hline & & & & & t & d. $f$ & Sig. (2-tailed) & Mean Difference \\
\hline \multirow{3}{*}{$\begin{array}{l}\text { Littering by people coming } \\
\text { to Markets }\end{array}$} & up to 5 & 82 & 3.48 & 0.94 & -0.88 & 99 & 0.377 & -0.209 \\
\hline & 6 to 20 & 19 & 3.68 & 0.82 & -0.96 & 30 & 0.340 & -0.209 \\
\hline & More than 20 & 5 & 3.4 & 0.89 & 0.18 & 4 & 0.863 & 0.076 \\
\hline \multirow{3}{*}{$\begin{array}{l}\text { Littering by different } \\
\text { transport drivers }\end{array}$} & up to 5 & 82 & 2.35 & 0.99 & 0.35 & 99 & 0.722 & 0.091 \\
\hline & 6 to 20 & 19 & 2.26 & 0.99 & 0.35 & 27 & 0.723 & 0.091 \\
\hline & More than 20 & 5 & 2.4 & 0.89 & -0.11 & 4 & 0.916 & -0.046 \\
\hline \multirow{3}{*}{$\begin{array}{l}\text { Non-Availability of } \\
\text { suitable size dustbins }\end{array}$} & up to 5 & 82 & 3.99 & 1.23 & 0.79 & 99 & 0.426 & 0.251 \\
\hline & 6 to 20 & 19 & 3.74 & 1.24 & 0.79 & 26 & 0.433 & 0.251 \\
\hline & More than 20 & 5 & 4.2 & 0.83 & -0.53 & 5 & 0.616 & -0.212 \\
\hline Ineffectiveness of & up to 5 & 82 & 3.48 & 1.70 & 0.69 & 99 & 0.491 & 0.318 \\
\hline Shopkeepers/Market & 6 to 20 & 19 & 3.16 & 2.19 & 0.59 & 23 & 0.56 & 0.318 \\
\hline Association & More than 20 & 5 & 2.8 & 0.83 & 1.61 & 6 & 0.156 & 0.676 \\
\hline Ineffectiveness of & up to 5 & 82 & 3.26 & 1.19 & -1.37 & 99 & 0.173 & -0.481 \\
\hline Municipality towards & 6 to 20 & 19 & 3.74 & 1.99 & -1.00 & 21 & 0.324 & -0.481 \\
\hline Cleaning Operations & More than 20 & 5 & 4 & 0.70 & -2.17 & 5 & 0.077 & -0.744 \\
\hline Lack of synchronization of & up to 5 & 82 & 4.1 & 1.02 & 2.04 & 99 & 0.043 & 0.519 \\
\hline collection chain of garbage & 6 to 20 & 19 & 3.58 & 0.83 & 2.32 & 31 & 0.027 & 0.519 \\
\hline from dustbins & More than 20 & 5 & 4.2 & 0.44 & -0.44 & 6 & 0.669 & -0.102 \\
\hline
\end{tabular}

Ineffectiveness of Shopkeepers/Market Association, shopkeepers with up to 5 employees $(N=82)$ was associated with a $M=3.48(S D=1.70)$. By comparison shopkeepers with 6 - 20 employees $(N=19)$ were associated with $M=3.16$ $(S D=2.19)$ and shopkeepers with more than 20 employees $(N=5)$ were associated $M=2.80(S D=0.83)$. The independent t-statistics associated with shopkeepers with up to 5 employees was $\mathrm{t}(99)=0.69, \mathrm{p}=0.491$ whereas $\mathrm{t}$ statistics for shopkeepers with 6 to 20 employees was $t(23)=0.59$, $\mathrm{p}=0.560$ and $\mathrm{t}$ statistics associated with shopkeepers with more than 20 employees $t(6)=1.61, p=0.156$. Ineffectiveness of Municipality towards Cleaning Operations, shopkeepers with up to 5 employees $(N=82)$ was associated with a $M=3.26(S D=1.70)$. By comparison shopkeepers with $6-20$ employees $(N=19)$ were associated with $M=3.74(S D=2.19)$ and shopkeepers with more than 20 employees $(N=5)$ were associated $M=4.00(S D=0.83)$. The independent t-statistics associated with shopkeepers with up to 5 employees was $t$ $(99)=-1.37, p=0.173$ Whereas $t$ statistics for shopkeepers with 6 to 20 employees was $\mathrm{t}(21)=-1.00, \mathrm{p}=0.324$ and $\mathrm{t}$ statistics associated with shopkeepers with more than 20 employees $t(5)=-2.17, p=0.077$. Lack of synchronization of collection chain of garbage from dustbins, shopkeepers with up to 5 employees $(N=82)$ was associated with a $M=4.10$ $(S D=1.02)$. By comparison shopkeepers with $6-20$ employees $(N=19)$ were associated with $M=3.58(S D=0.83)$ and shopkeepers with more than 20 employees $(N=5)$ were associated $M=4.20(S D=0.44)$. The independent t-statistics associated with shopkeepers with up to 5 employees was $\mathrm{t}$ $(99)=2.04, p=0.0 .43$ whereas $t$ statistics for shopkeepers with 6 to 20 employees was $\mathrm{t}(31)=2.32, \mathrm{p}=0.027$ and $\mathrm{t}$ statistics associated with shopkeepers with more than 20 employees $t$ (6) $=-0.44, p=0.669$.

\subsection{Effective Ways to Ensure Total Cleanliness}

To test the hypothesis that the opinions of shopkeepers with 5 employees, six to twenty and more than twenty employees were associated with reference to effectiveness of 
various ways to ensure complete cleanliness be statistically significant different mean, an independent t-test was performed. As can be seen in Table 3, for the parameter Municipality officials' Commitment, shopkeepers with up to 5 employees $(N=82)$ was associated with a $M=4.06$ $(S D=0.98)$. By comparison shopkeepers with $6-20$ employees $(N=19)$ were associated with $M=3.68(S D=0.88)$ and shopkeepers with more than 20 employees $(N=5)$ were associated $M=4.00(S D=0.00)$. The independent t-statistics associated with shopkeepers with up to 5 employees was $t$ $(99)=1.52, p=0.130$ Whereas $t$ statistics for shopkeepers with 6 to 20 employees was $\mathrm{t}(29)=1.63, \mathrm{p}=0.113$ and $\mathrm{t}$ statistics associated with shopkeepers with more than 20 employees $t$ $(81)=0.56, p=0.577$. Market Associations Commitment, shopkeepers with up to 5 employees $(N=82)$ was associated with a $M=3.61(S D=1.42)$. By comparison shopkeepers with 6 - 20 employees $(N=19)$ were associated with $M=3.74$ $(S D=0.73)$ and shopkeepers with more than 20 employees
$(N=5)$ were associated $M=3.60(S D=0.89)$. The independent t-statistics associated with shopkeepers with up to 5 employees was $t(99)=-0.37, p=0.708$ whereas $t$ statistics for shopkeepers with 6 to 20 employees was $t(54)=-0.55$, $\mathrm{p}=0.584$ and $\mathrm{t}$ statistics associated with shopkeepers with more than 20 employees $\mathrm{t}(5)=0.02, \mathrm{p}=0.983$. Use of Tech based cleaning equipment, shopkeepers with up to 5 employees $(N=82)$ was associated with a $M=3.88(S D=0.88)$. By comparison shopkeepers with $6-20$ employees $(N=19)$ were associated with $M=3.89(S D=0.73)$ and shopkeepers with more than 20 employees $(N=5)$ were associated $M=4.2$ $(S D=0.44)$. The independent t-statistics associated with shopkeepers with up to 5 employees was $t(99)=-0.07$, $\mathrm{p}=0.939$ Whereas $\mathrm{t}$ statistics for shopkeepers with 6 to 20 employees was $\mathrm{t}(31)=-0.08, \mathrm{p}=0.932$ and $\mathrm{t}$ statistics associated with shopkeepers with more than 20 employees $t$ (6) $=-1.44, p=0.197$.

Table 3. Extent of effectiveness of various ways to ensure total cleanliness.

\begin{tabular}{|c|c|c|c|c|c|c|c|c|}
\hline \multirow{2}{*}{ Parameters } & \multirow{2}{*}{ No of Employees in shops } & \multirow{2}{*}{$\mathbf{N}$} & \multirow{2}{*}{ Mean } & \multirow{2}{*}{ Std. Deviation } & \multicolumn{4}{|c|}{ t-test for Equality of Means } \\
\hline & & & & & t & df & Sig. (2-tailed) & Mean Difference \\
\hline \multirow{3}{*}{$\begin{array}{l}\text { Municipality officials' } \\
\text { Commitment }\end{array}$} & up to 5 & 82 & 4.06 & 0.98 & 1.52 & 99 & 0.13 & 0.377 \\
\hline & 6 to 20 & 19 & 3.68 & 0.88 & 1.63 & 29 & 0.113 & 0.377 \\
\hline & More than 20 & 5 & 4.00 & 0.00 & 0.56 & 81 & 0.577 & 0.061 \\
\hline \multirow{3}{*}{ Market Associations Commitment } & up to 5 & 82 & 3.61 & 1.42 & -0.37 & 99 & 0.708 & -0.127 \\
\hline & 6 to 20 & 19 & 3.74 & 0.73 & -0.55 & 54 & 0.584 & -0.127 \\
\hline & More than 20 & 5 & 3.6 & 0.89 & 0.02 & 5 & 0.983 & 0.01 \\
\hline \multirow{3}{*}{$\begin{array}{l}\text { Use of Tech based cleaning } \\
\text { equipment }\end{array}$} & up to 5 & 82 & 3.88 & 0.88 & -0.07 & 99 & 0.939 & -0.017 \\
\hline & 6 to 20 & 19 & 3.89 & 0.73 & -0.08 & 31 & 0.932 & -0.017 \\
\hline & More than 20 & 5 & 4.2 & 0.44 & -1.44 & 6 & 0.197 & -0.322 \\
\hline \multirow{3}{*}{$\begin{array}{l}\text { Enhancement of manpower by } \\
\text { Municipal Bodies }\end{array}$} & up to 5 & 82 & 3.18 & 1.49 & -0.57 & 99 & 0.570 & -0.238 \\
\hline & 6 to 20 & 19 & 3.42 & 2.19 & -0.45 & 22 & 0.657 & -0.238 \\
\hline & More than 20 & 5 & 2.40 & 0.89 & 1.81 & 5 & 0.125 & 0.783 \\
\hline \multirow{3}{*}{$\begin{array}{l}\text { Enhancement of manpower by } \\
\text { RWA }\end{array}$} & up to 5 & 82 & 3.01 & 1.48 & -0.34 & 99 & 0.728 & -0.146 \\
\hline & 6 to 20 & 19 & 3.16 & 2.21 & -0.27 & 21 & 0.788 & -0.146 \\
\hline & More than 20 & 5 & 2.60 & 0.89 & 0.95 & 5 & 0.381 & 0.412 \\
\hline \multirow{3}{*}{$\begin{array}{l}\text { Improvement of attitude of } \\
\text { cleaning workers towards } \\
\text { cleanliness }\end{array}$} & up to 5 & 82 & 4.3 & 0.64 & 1.76 & 99 & 0.08 & 0.305 \\
\hline & 6 to 20 & 19 & 4 & 0.81 & 1.52 & 23 & 0.141 & 0.305 \\
\hline & More than 20 & 5 & 4.00 & 0.00 & 4.30 & 81 & 0 & 0.305 \\
\hline \multirow{3}{*}{$\begin{array}{l}\text { Provision of large size dustbins in } \\
\text { the markets, nearby areas }\end{array}$} & up to 5 & 82 & 4.29 & 0.71 & -0.12 & 99 & 0.9 & -0.023 \\
\hline & 6 to 20 & 19 & 4.32 & 0.74 & -0.12 & 26 & 0.904 & -0.023 \\
\hline & More than 20 & 5 & 4.2 & 0.44 & 0.43 & 5 & 0.683 & 0.093 \\
\hline \multirow{3}{*}{$\begin{array}{l}\text { Synchronization of collection chain } \\
\text { of garbage from dustbins }\end{array}$} & up to 5 & 81 & 4.05 & 0.54 & -0.02 & 98 & 0.981 & -0.003 \\
\hline & 6 to 20 & 19 & 4.05 & 0.52 & -0.02 & 27 & 0.981 & -0.003 \\
\hline & More than 20 & 5 & 4.000 & 0.000 & 0.81 & 80 & 0.418 & 0.049 \\
\hline \multirow{3}{*}{ Stoppage of littering by people } & up to 5 & 82 & 3.89 & 0.75 & -0.02 & 99 & 0.981 & -0.004 \\
\hline & 6 to 20 & 19 & 3.89 & 0.56 & -0.02 & 34 & 0.977 & -0.004 \\
\hline & More than 20 & 5 & 3.4 & 0.89 & 1.2 & 4 & 0.291 & 0.49 \\
\hline \multirow{3}{*}{$\begin{array}{l}\text { Stoppage of Garbage throwing by } \\
\text { whosoever }\end{array}$} & up to 5 & 82 & 3.84 & 0.79 & -0.003 & 99 & 0.997 & -0.001 \\
\hline & 6 to 20 & 19 & 3.84 & 0.76 & -0.003 & 27 & 0.997 & -0.001 \\
\hline & More than 20 & 5 & 3.40 & 0.89 & 1.07 & 4 & 0.337 & 0.441 \\
\hline \multirow{3}{*}{$\begin{array}{l}\text { Removal of Malba after road } \\
\text { digging by govt agencies }\end{array}$} & up to 5 & 82 & 3.87 & 0.76 & -0.16 & 99 & 0.873 & -0.029 \\
\hline & 6 to 20 & 19 & 3.89 & 0.31 & -0.26 & 71 & 0.796 & -0.029 \\
\hline & More than 20 & 5 & 3.40 & 0.89 & 1.13 & 4 & 0.313 & 0.466 \\
\hline \multirow{3}{*}{$\begin{array}{l}\text { Removal of Malba after } \\
\text { completion of digging work by } \\
\text { govt agencies }\end{array}$} & up to 5 & 82 & 3.88 & 0.79 & -0.09 & 99 & 0.929 & -0.017 \\
\hline & 6 to 20 & 19 & 3.89 & 0.31 & -0.14 & 73 & 0.883 & -0.017 \\
\hline & More than 20 & 5 & 3.40 & 0.89 & 1.16 & 4 & 0.302 & 0.478 \\
\hline \multirow{3}{*}{$\begin{array}{l}\text { Removal of Malba after road } \\
\text { digging by Contractors/ House } \\
\text { owners }\end{array}$} & up to 5 & 82 & 3.90 & 0.73 & -0.26 & 99 & 0.792 & -0.045 \\
\hline & 6 to 20 & 19 & 3.95 & 0.22 & -0.46 & 90 & 0.642 & -0.045 \\
\hline & More than 20 & 5 & 3.40 & 0.89 & 1.23 & 4 & 0.281 & 0.502 \\
\hline \multirow{3}{*}{$\begin{array}{l}\text { Effective collection and } \\
\text { composting of dry leaves }\end{array}$} & up to 5 & 82 & 4.18 & 1.24 & 1.32 & 99 & 0.189 & 0.393 \\
\hline & 6 to 20 & 19 & 3.79 & 0.71 & 1.83 & 47 & 0.072 & 0.393 \\
\hline & More than 20 & 5 & 3.40 & 0.89 & 1.85 & 5 & 0.123 & 0.783 \\
\hline
\end{tabular}




\begin{tabular}{|c|c|c|c|c|c|c|c|c|}
\hline \multirow{2}{*}{ Parameters } & \multirow{2}{*}{ No of Employees in shops } & \multirow{2}{*}{$\mathbf{N}$} & \multirow{2}{*}{ Mean } & \multirow{2}{*}{ Std. Deviation } & \multicolumn{4}{|c|}{ t-test for Equality of Means } \\
\hline & & & & & $\mathrm{t}$ & df & Sig. (2-tailed) & Mean Difference \\
\hline \multirow{3}{*}{$\begin{array}{l}\text { Effective stoppage of dropping } \\
\text { garbage bags on roadsides }\end{array}$} & up to 5 & 82 & 3.94 & 0.67 & 0.27 & 99 & 0.781 & 0.044 \\
\hline & 6 to 20 & 19 & 3.89 & 0.31 & 0.42 & 60 & 0.671 & 0.044 \\
\hline & More than 20 & 5 & 3.40 & 0.89 & 1.32 & 4 & 0.252 & 0.539 \\
\hline \multirow{3}{*}{$\begin{array}{l}\text { Effective closing of large dustbins } \\
\text { to prevent animals from taking out } \\
\text { eatables from garbage }\end{array}$} & up to 5 & 82 & 3.80 & 0.80 & 0.60 & 99 & 0.547 & 0.121 \\
\hline & 6 to 20 & 19 & 3.68 & 0.67 & 0.67 & 31 & 0.503 & 0.121 \\
\hline & More than 20 & 5 & 3.80 & 0.44 & 0.022 & 5 & 0.983 & 0.005 \\
\hline \multirow{3}{*}{$\begin{array}{l}\text { Elimination of Street dogs to end } \\
\text { problem of their potty }\end{array}$} & up to 5 & 82 & 3.35 & 1.22 & -0.38 & 99 & 0.704 & -0.12 \\
\hline & 6 to 20 & 19 & 3.47 & 1.30 & -0.36 & 25 & 0.718 & -0.12 \\
\hline & More than 20 & 5 & 4 & 0.00 & -4.79 & 81 & 0 & -0.646 \\
\hline \multirow{3}{*}{$\begin{array}{l}\text { Owners of pet dogs to take potty } \\
\text { with them }\end{array}$} & up to 5 & 82 & 3.93 & 0.96 & -0.32 & 99 & 0.746 & -0.073 \\
\hline & 6 to 20 & 19 & 4 & 0.33 & -0.55 & 84 & 0.579 & -0.073 \\
\hline & More than 20 & & 4 & 0.00 & -0.68 & 81 & 0.495 & -0.073 \\
\hline \multirow{3}{*}{$\begin{array}{l}\text { Making participation in "Garbage } \\
\text { Collection System" mandatory }\end{array}$} & up to 5 & 82 & 3.91 & 0.63 & -0.93 & 99 & 0.353 & -0.138 \\
\hline & 6 to 20 & 19 & 4.05 & 0.22 & -1.57 & 81 & 0.118 & -0.138 \\
\hline & More than 20 & 5 & 4 & 0.00 & -1.22 & 81 & 0.225 & -0.085 \\
\hline \multirow{3}{*}{$\begin{array}{l}\text { Removal of slum(s) away from the } \\
\text { market area }\end{array}$} & up to 5 & 82 & 2.83 & 1.46 & -0.85 & 99 & 0.395 & -0.329 \\
\hline & 6 to 20 & 19 & 3.16 & 1.70 & -0.77 & 24 & 0.446 & -0.329 \\
\hline & More than 20 & 5 & 2.80 & 1.09 & 0.057 & 4 & 0.957 & 0.029 \\
\hline \multirow{3}{*}{$\begin{array}{l}\text { Removal of Renbasera(s) away } \\
\text { from the market area }\end{array}$} & up to 5 & 82 & 2 & 0.90 & -1.62 & 99 & 0.107 & -0.368 \\
\hline & 6 to 20 & 19 & 2.37 & 0.83 & -1.71 & 28 & 0.097 & -0.368 \\
\hline & More than 20 & 5 & 2.40 & 0.89 & -0.97 & 4 & 0.381 & -0.4 \\
\hline
\end{tabular}

Enhancement of manpower by Municipal Bodies, shopkeepers with up to 5 employees $(N=82)$ was associated with a $M=3.18(S D=1.49)$. By comparison shopkeepers with 6 - 20 employees $(N=19)$ were associated with $M=3.42$ $(S D=2.19)$ and shopkeepers with more than 20 employees $(N=5)$ were associated $M=2.40(S D=0.89)$. The independent t-statistics associated with shopkeepers with up to 5 employees was $t(99)=-0.57, p=0.570$ whereas $t$ statistics for shopkeepers with 6 to 20 employees was $t(22)=-0.45$, $\mathrm{p}=0.657$ and $\mathrm{t}$ statistics associated with shopkeepers with more than 20 employees $t(5)=1.81, p=0.125$. Enhancement of manpower by RWA, shopkeepers with up to 5 employees $(N=82)$ was associated with a $M=3.01 \quad(S D=1.48)$. By comparison shopkeepers with $6-20$ employees $(N=19)$ were associated with $M=3.16(S D=2.21)$ and shopkeepers with more than 20 employees $(N=5)$ were associated $M=2.60$ $(S D=0.89)$. The independent t-statistics associated with shopkeepers with up to 5 employees was $t(99)=-0.34$, $\mathrm{p}=0.728$ Whereas $\mathrm{t}$ statistics for shopkeepers with 6 to 20 employees was $\mathrm{t}(22)=-0.27, \mathrm{p}=0.788$ and $\mathrm{t}$ statistics associated with shopkeepers with more than 20 employees $t$ $(5)=0.95, p=0.381$.

Improvement of attitude of cleaning workers towards cleanliness, shopkeepers with up to 5 employees $(N=82)$ was associated with a $M=4.43 \quad(S D=0.64)$. By comparison shopkeepers with $6-20$ employees $(N=19)$ were associated with $M=4(S D=0.81)$ and shopkeepers with more than 20 employees $(N=5)$ were associated $M=4 \quad(S D=0)$. The independent t-statistics associated with shopkeepers with up to 5 employees was $t(99)=1.76, p=0.080$ whereas t statistics for shopkeepers with 6 to 20 employees was $t(23)=1.52$, $\mathrm{p}=0.141$ and $\mathrm{t}$ statistics associated with shopkeepers with more than 20 employees $\mathrm{t}(81)=4.30, \mathrm{p}=0$. Provision of large size dustbins in the markets, nearby areas, shopkeepers with up to 5 employees $(N=82)$ was associated with a $M=4.29$ $(S D=0.71)$. By comparison shopkeepers with $6-20$ employees $(N=19)$ were associated with $M=4.32(S D=0.74)$ and shopkeepers with more than 20 employees $(N=5)$ were associated $M=4.20(S D=0.44)$. The independent t-statistics associated with shopkeepers with up to 5 employees was $t$ $(99)=-0.12, p=0.90$ whereas $t$ statistics for shopkeepers with 6 to 20 employees was $t(26)=1.52, p=0.904$ and $t$ statistics associated with shopkeepers with more than 20 employees $t$ $(5)=0.43, p=0.683$. Synchronization of collection chain of garbage from dustbins, shopkeepers with up to 5 employees $(N=82)$ was associated with a $M=4.05(S D=0.54)$. By comparison shopkeepers with $6-20$ employees $(N=19)$ were associated with $M=4.05(S D=0.52)$ and shopkeepers with more than 20 employees $(N=5)$ were associated $M=4.00$ $(S D=0)$. The independent t-statistics associated with shopkeepers with up to 5 employees was $\mathrm{t}(98)=-0.02$, $\mathrm{p}=0.981$ Whereas $\mathrm{t}$ statistics for shopkeepers with 6 to 20 employees was $\mathrm{t}(27)=-0.02, \mathrm{p}=0.981$ and $\mathrm{t}$ statistics associated with shopkeepers with more than 20 employees $t$ $(80)=0.81, \mathrm{p}=0.418$. Stoppage of littering by people, shopkeepers with up to 5 employees $(N=82)$ was associated with a $M=3.89(S D=0.75)$. By comparison shopkeepers with 6 - 20 employees $(N=19)$ were associated with $M=3.89$ $(S D=0.56)$ and shopkeepers with more than 20 employees $(N=5)$ were associated $M=3.4(S D=0.89)$. The independent tstatistics associated with shopkeepers with up to 5 employees was $\mathrm{t}(99)=-0.02, \mathrm{p}=0.981$ whereas $\mathrm{t}$ statistics for shopkeepers with 6 to 20 employees was t $(34)=-0.02$, $\mathrm{p}=0.977$ and $\mathrm{t}$ statistics associated with shopkeepers with more than 20 employees $t(4)=1.2, p=0.291$.

Stoppage of Garbage throwing by whosoever, shopkeepers with up to 5 employees $(N=82)$ was associated with a $M=3.84(S D=0.79)$. By comparison shopkeepers with $6-20$ employees $(N=19)$ were associated with $M=3.84(S D=0.76)$ and shopkeepers with more than 20 employees $(N=5)$ were associated $M=3.40(S D=0.89)$. The independent t-statistics associated with shopkeepers with up to 5 employees was $t$ (99) $=-0.003, p=0.997$ whereas $t$ statistics for shopkeepers with 6 to 20 employees was $t(27)=-0.003, p=0.997$ and $t$ 
statistics associated with shopkeepers with more than 20 employees t (4)=1.07, $p=0.337$. Removal of Malba after road digging by government agencies, shopkeepers with up to 5 employees $(N=82)$ was associated with a $M=3.87(S D=0.76)$. By comparison shopkeepers with $6-20$ employees $(N=19)$ were associated with $M=3.89(S D=0.31)$ and shopkeepers with more than 20 employees $(N=5)$ were associated $M=3.40$ $(S D=0.89)$. The independent t-statistics associated with shopkeepers with up to 5 employees was $t(99)=-0.16$, $\mathrm{p}=0.873$ whereas $\mathrm{t}$ statistics for shopkeepers with 6 to 20 employees was $\mathrm{t}(27)=-0.26, \mathrm{p}=0.796$ and $\mathrm{t}$ statistics associated with shopkeepers with more than 20 employees $t$ $(4)=1.13, p=0.313$. Removal of Malba after completion of digging work by government agencies, shopkeepers with up to 5 employees $(N=82)$ was associated with a $M=3.88$ $(S D=0.79)$. By comparison shopkeepers with $6-20$ employees $(N=19)$ were associated with $M=3.89(S D=0.31)$ and shopkeepers with more than 20 employees $(N=5)$ were associated $M=3.40(S D=0.89)$. The independent t-statistics associated with shopkeepers with up to 5 employees was $t$ $(99)=-0.09, p=0.929$ whereas $t$ statistics for shopkeepers with 6 to 20 employees was $t(73)=-0.14, p=0.883$ and $t$ statistics associated with shopkeepers with more than 20 employees $t$ (4) $=1.16, p=0.302$. Removal of Malba after road digging by Contractors/ House owners, shopkeepers with up to 5 employees $(N=82)$ was associated with a $M=3.90(S D=0.79)$. By comparison shopkeepers with $6-20$ employees $(N=19)$ were associated with $M=3.95(S D=0.73)$ and shopkeepers with more than 20 employees $(N=5)$ were associated $M=3.40$ $(S D=0.22)$. The independent t-statistics associated with shopkeepers with up to 5 employees was $t(99)=-0.09$, $\mathrm{p}=0.792$ whereas $\mathrm{t}$ statistics for shopkeepers with 6 to 20 employees was $t(90)=-0.14, p=0.642$ and $t$ statistics associated with shopkeepers with more than 20 employees $t$ $(4)=1.16, p=0.281$. Effective collection and composting of dry leaves, shopkeepers with up to 5 employees $(N=82)$ was associated with a $M=4.18 \quad(S D=1.24)$. By comparison shopkeepers with $6-20$ employees $(N=19)$ were associated with $M=3.79(S D=0.71)$ and shopkeepers with more than 20 employees $(N=5)$ were associated $M=3.40(S D=0.89)$. The independent t-statistics associated with shopkeepers with up to 5 employees was $\mathrm{t}(99)=1.32, \mathrm{p}=0.189$ whereas $\mathrm{t}$ statistics for shopkeepers with 6 to 20 employees was $t(47)=1.83$, $\mathrm{p}=0.072$ and $\mathrm{t}$ statistics associated with shopkeepers with more than 20 employees $t(5)=1.85, p=0.123$.

Effective stoppage of dropping garbage bags on roadsides, shopkeepers with up to 5 employees $(N=82)$ was associated with an $M=3.94(S D=0.67)$. By comparison shopkeepers with $6-20$ employees $(N=19)$ were associated with $M=3.89$ $(S D=0.31)$ and shopkeepers with more than 20 employees $(N=5)$ were associated $M=3.40(S D=0.89)$. The independent t-statistics associated with shopkeepers with up to 5 employees was $\mathrm{t}(99)=0.27, \mathrm{p}=0.781$ Whereas $\mathrm{t}$ statistics for shopkeepers with 6 to 20 employees was $t(60)=0.42$, $\mathrm{p}=0.671$ and $\mathrm{t}$ statistics associated with shopkeepers with more than 20 employees $t(4)=1.32, p=0.252$. Effective closing of large dustbins to prevent animals from taking out eatables from garbage, shopkeepers with up to 5 employees $(N=82)$ was associated with a $M=3.80 \quad(S D=0.80)$. By comparison shopkeepers with $6-20$ employees $(N=19)$ were associated with $M=3.68(S D=0.67)$ and shopkeepers with more than 20 employees $(N=5)$ were associated $M=3.80$ $(S D=0.44)$. The independent t-statistics associated with shopkeepers with up to 5 employees was $t(99)=0.60$, $\mathrm{p}=0.547$ whereas $\mathrm{t}$ statistics for shopkeepers with 6 to 20 employees was $\mathrm{t}(31)=0.67, \mathrm{p}=0.503$ and $\mathrm{t}$ statistics associated with shopkeepers with more than 20 employees $t$ $(5)=0.022, p=0.983$. Elimination of Street dogs to end problem of their potty, shopkeepers with up to 5 employees $(N=82)$ was associated with a $M=3.35(S D=1.22)$. By comparison shopkeepers with $6-20$ employees $(N=19)$ were associated with $M=3.47(S D=1.30)$ and shopkeepers with more than 20 employees $(N=5)$ were associated $M=4.00$ $(S D=0)$. The independent t-statistics associated with shopkeepers with up to 5 employees was $t(99)=-0.48$, $p=0.704$ whereas $t$ statistics for shopkeepers with 6 to 20 employees was $\mathrm{t}(25)=-0.36, \mathrm{p}=0.718$ and $\mathrm{t}$ statistics associated with shopkeepers with more than 20 employees $t$ $(81)=-4.79, p=0$. Owners of pet dogs to take potty with them, shopkeepers with up to 5 employees $(N=82)$ was associated with a $M=3.93(S D=0.96)$. By comparison shopkeepers with 6 - 20 employees $(N=19)$ were associated with $M=4.00$ $(S D=1.33)$ and shopkeepers with more than 20 employees $(N=5)$ were associated $M=4.00(S D=0)$. The independent tstatistics associated with shopkeepers with up to 5 employees was $\mathrm{t}(99)=-0.32, \quad \mathrm{p}=0.746$ whereas $\mathrm{t}$ statistics for shopkeepers with 6 to 20 employees was $t(84)=-0.55$, $\mathrm{p}=0.579$ and $\mathrm{t}$ statistics associated with shopkeepers with more than 20 employees $\mathrm{t}(81)=-0.68, \mathrm{p}=0.495$.

Making participation in "Garbage Collection System" mandatory, shopkeepers with up to 5 employees $(N=82)$ was associated with a $M=3.91 \quad(S D=0.63)$. By comparison shopkeepers with $6-20$ employees $(N=19)$ were associated with $M=4.05(S D=0.22)$ and shopkeepers with more than 20 employees $(N=5)$ were associated $M=4.00 \quad(S D=0)$. The independent $\mathrm{t}$-statistics associated with shopkeepers with up to 5 employees was $\mathrm{t}(99)=-0.93, \mathrm{p}=0.353$ whereas $t$ statistics for shopkeepers with 6 to 20 employees was $t(81)=-1.57$, $\mathrm{p}=0.118$ and $\mathrm{t}$ statistics associated with shopkeepers with more than 20 employees $t(81)=-1.22, p=0.225$. Removal of slum(s) away from the market area, shopkeepers with up to 5 employees $(N=82)$ was associated with a $M=2.83(S D=1.46)$. By comparison shopkeepers with $6-20$ employees $(N=19)$ were associated with $M=3.16(S D=1.70)$ and shopkeepers with more than 20 employees $(N=5)$ were associated $M=2.80$ $(S D=1.09)$. The independent t-statistics associated with shopkeepers with up to 5 employees was $t(99)=-0.85$, $\mathrm{p}=0.395$ whereas $\mathrm{t}$ statistics for shopkeepers with 6 to 20 employees was $\mathrm{t}(24)=-0.77, \mathrm{p}=0.446$ and $\mathrm{t}$ statistics associated with shopkeepers with more than 20 employees $t$ (4) $=0.057, \mathrm{p}=0.957$. Removal of Renbasera (s) away from the market area, shopkeepers with up to 5 employees $(N=82)$ was associated with an $M=2.00(S D=0.90)$. By comparison shopkeepers with $6-20$ employees $(N=19)$ were associated 
with $M=2.37(S D=0.83)$ and shopkeepers with more than 20 employees $(N=5)$ were associated $M=2.40(S D=0.89)$. The independent $t$-statistics associated with shopkeepers with up to 5 employees was $\mathrm{t}(99)=-1.62, \mathrm{p}=0.107$ whereas $\mathrm{t}$ statistics for shopkeepers with 6 to 20 employees was t $(24)=-1.71$, $\mathrm{p}=0.097$ and $\mathrm{t}$ statistics associated with shopkeepers with more than 20 employees $t(4)=-0.97, p=0.381$.

\section{Conclusion}

The paper is attempted to understand the opinions of shopkeepers from various markets in New Delhi regarding cleanliness. Three categories of shopkeepers were surveyed for the purpose of this study. First category of shopkeepers surveyed had up to 5 employees. Second category was the ones which had 6- 20 employees and the third category of shopkeepers has more than 20 employees. To test the hypothesis that shopkeepers with up to 5 employees, 6-20 employees and more than 20 employees had statistically significant different opinions regarding cleanliness an independent $\mathrm{t}$ - test is performed.

The results from the t-test highlight, that the opinions of all three categories of shopkeepers are not statistically significantly different. All the shopkeepers from different categories have similar opinions on parameters being tested for the extent of contribution towards creation of garbage while also on parameters for the shopkeeper's thought were efficient to ensure complete cleanliness in New Delhi. It can be concluded after testing hypothesis that the opinion of shopkeepers from different markets in New Delhi on all parameters, ways to ensure total cleanliness, limitations/ constraints towards lack of cleanliness and extent of contribution towards creation of garbage are not statistically significantly different. Hence Hypothesis is rejected as the opinion of shopkeepers of all three categories not varies based on increasing number of employees. It can be concluded that all the select shopkeepers in a sample agreed to the extent of contribution to the garbage, limitation or constraints of lack of cleanliness and effective ways to ensure total cleanliness.

\section{Future Scope of Research}

There is requirement of follow-up empirical research work as this paper is based on opinion of one of the important stakeholders, Shopkeepers regarding problem of lack of cleanliness in urban India with special reference to Delhi being Capital of India. Because, India could attract more tourists due to its own rich heritage, however, lack of cleanliness is one of the reasons for the low footfall of foreign tourist. Low footfall of foreign tourist hampers the foreign exchange earnings whereby significantly increase in unemployment. Hence, there is scope of follow-up empirical research based on survey for other stakeholders like Households, Municipal Corporations and other Government organizations to seek their opinions on the parameters of cleanliness, ways to ensure total cleanliness, limitations or constraints towards lack of cleanliness and extent of contribution towards creation of garbage, and prepare paper on policy recommendations to the state government based on opinion of important stakeholders for cleanliness in Delhi. The policy recommendations to the state of Delhi may be implemented in other states also with minor changes as per requirement of respective states.

\section{Acknowledgements}

Authors are pleased to acknowledge continued support provided by the Ministry of Human Resource Development (IMPRESS Scheme) and Indian Council of Social Science Research.

\section{References}

[1] McAndrew, F. T. (1993). Environmental Psychology. Pacific Grove, CA: Brooks/Cole.

[2] Ockels, J. H. (2003). Local Control of Illegal Dumping. Pottsboro, TX: Little Mineral Pres.

[3] Corvellec, H., Bramryd, T. Hultman, J., 2011. The business model of solid waste management in Sweden - a case study of two municipally-owned companies. Waste Management Research, 30 (5), pp. 512-518.

[4] Dutta, N. et al., 2019. Climate Change in Hilly Regions of India: Issues and Challenges in Waste Management. Sustainable Waste Management: Policies and Case Studies, pp. 657-669.

[5] Geller, E. S., Witmer, J. F. Tuso, M. A., 1977. Environmental interventions for litter control. Journal of Applied Psychology, 62 (3), pp. 344-351.

[6] Huffman, K. T. et al., 1995. Litter Reduction. Environment and Behavior, 27 (2), pp. 153-183.

[7] Epstein, J. J., Hammett, T. M. and Collins, L. (1995). Law Enforcement Response to Environmental Crime. National Institute of Justice.

[8] Zaman Uz Atiq, (2016), A comprehensive study of the Environmental and economic benefits of resource recovery from global waste management systems.

[9] Gupta, H. et al., 2019. A conceptual framework of internet of things for efficient municipal solid waste management and waste to energy implementation. International Journal of Environment and Waste Management, 23 (4), p. 410.

[10] Hazra, T., Goel, S. Maitra, B., 2013. Willingness-to-pay for solid waste management service attributes: Kolkata Municipal Corporation area, India, as a case study. International Journal of Environment and Waste Management, 12 (4), p. 406.

[11] Husaini, I. et al., 2007. European household waste management schemes: Their effectiveness and applicability in England. Resources, Conservation and Recycling, 51 (1), pp. 248-263.

[12] Jain, S., Singhal, S. Pandey, S., 2020. Environmental life cycle assessment of construction and demolition waste recycling: A case of urban India. Resources, Conservation and Recycling, 155, p. 104642 
[13] Jha, A. K. et al., 2008. Greenhouse gas emissions from municipal solid waste management in Indian mega-cities: A case study of Chennai landfill sites. Chemosphere, 71 (4), pp. 750-758.

[14] Joshi, R. Ahmed, S., 2016. Status and challenges of municipal solid waste management in India: A review. Cogent Environmental Science, 2 (1).

[15] Mastakar, P. et al., 2019. Zero Waste Circular Model of MSWM: A Success in Ward 40, Pune, India. Metamorphosis: A Journal of Management Research, 18 (1), pp. 36-56.

[16] Matsuda, T. et al., 2012. Life-cycle greenhouse gas inventory analysis of household waste management and food waste reduction activities in Kyoto, Japan. The International Journal of Life Cycle Assessment, 17 (6), pp. 743-752.

[17] Mcfarlane, C., 2008. Sanitation in Mumbai's Informal Settlements: State, 'Slum', and Infrastructure. Environment and Planning A: Economy and Space, 40 (1), pp. 88-107.

[18] Parashar, C. K. et al., 2019. Municipal Solid Wastes-A Promising Sustainable Source of Energy: A Review on Different Waste-to-Energy Conversion Technologies. Energy Recovery Processes from Wastes, pp. 151-163.
[19] Parihar, R. S. et al., 2019. MSWM in Bhopal city: a critical analysis and a roadmap for its sustainable management. Proceedings of the Institution of Civil Engineers - Municipal Engineer, 172 (2), pp. 83-95.

[20] Priti \& Mandal, K., 2019. Review on evolution of municipal solid waste management in India: practices, challenges and policy implications. Journal of Material Cycles and Waste Management, 21 (6), pp. 1263-1279.

[21] Silva, A. et al., 2016. The role of policy labels, keywords and framing in transitioning waste policy. Journal of Cleaner Production, 115, pp. 224-237.

[22] Singh, A. \& Raj, P., 2018. Sustainable recycling model for municipal solid waste in Patna. Energy \& Environment, 30 (2), pp. 212-234.

[23] Vivekananda, B. \& Nema, A. K., 2014. Forecasting of solid waste quantity and composition: a multilinear regression and system dynamics approach. International Journal of Environment and Waste Management, 13 (2), p. 179. 